\title{
Propolis Extract: A Possible Antiseptic Oral Care against Multidrug-Resistant Non-Fermenting Bacteria Isolated from Non-Ventilator Hospital-Acquired Pneumonia
}

\author{
Sylvana N. Gaber ${ }^{1 *}$ (D) Eman Elsayed Mahmoud Hemeda², Hebat-Allah Sayed \\ Elsayeh $^{3}$, Wafaa Y. Abdel Wahed ${ }^{4}$ D , Mahmoud A.F. Khalil ${ }^{5}$ and Enas G. Ibrahim ${ }^{1}$ \\ ${ }^{1}$ Department of Medical Microbiology and Immunology, Faculty of Medicine, Fayoum University, Fayoum, \\ Egypt. ${ }^{2}$ Department of Clinical and Chemical Pathology, Faculty of Medicine, Fayoum University, Fayoum, Egypt. \\ ${ }^{3}$ Departments of Apiculture Research, Plant Protectionsititue, A.R.C. ${ }^{4}$ Department of Public Health, Faculty of \\ Medicine, Fayoum University, Fayoum, Egypt. ${ }^{5}$ Department of Medical Microbiology and Immunology, Faculty of \\ Pharmacy, Fayoum University, Fayoum, Egypt.
}

\begin{abstract}
Non-ventilator Hospital-acquired Pneumonia (NV-HAP) is a significant burden in acute care hospitals and poses a risk to nonelderly, non-intensive care unit (ICU) patients, which have been increasing worldwide. In addition, poor oral hygiene has been associated to significant increases in the number of cases of NV-HAP. Unfortunately, preventive options are limited. Thus, there is a need for oral antiseptics, similar to those of natural products or plant sources. The aim of this study was to assess the antibacterial activity of various bee products (BPs); for example, honey, propolis, and bee venom against multidrugresistant (MDR) non-fermenting bacteria (e.g., Pseudomonas and Acinetobacter), which were collected from NV-HAP patients to investigate its use as a possible antiseptic oral care. Bacterial susceptibility to different antibiotics were performed. The antimicrobial activity of BPs against non-fermenting bacteria, the minimum inhibitory concentration (MIC), and the minimum bactericidal concentration (MBC) were assessed. Eighteen Pseudomonas aeruginosa isolates and five Acinetobacter baumannii isolates were identified. $P$. aeruginos $a$ isolates displayed high resistance to the antibiotics: meropenem and imipenem (55.6\% and $\mathbf{7 7 . 8 \%}$ respectively), whereas $A$. baumannii isolates were $100 \%$ resistant to meropenem and imipenem. All isolates remained sensitive to colistin. Propolis showed the best antibacterial activity $(p<0.001)$ in comparison to honey and bee venom against $P$. aeruginosa $(13-36 \mathrm{~mm}, \mathrm{MIC}=1.4-22.5 \%$, and $\mathrm{MBC}=2.8-45 \%)$ and $A$. baumannii $(7-20 \mathrm{~mm}, \mathrm{MIC}=5.6-22.5 \%$, and $\mathrm{MBC}=11.3-22.5 \%)$. While bee venom expressed the least antibacterial activity against all isolates with a zone diameter ranging from 0-12 $\mathrm{mm}$, propolis, which is a non-toxic, natural, and inexpensive, had antibacterial activity towards the MDR bacteria: $P$. aeruginosa and $A$. baumannii collected from pneumonic patients. Additionally, we confirmed that propolis could be used as a potential antiseptic oral care product.
\end{abstract}

Keywords: Antimicrobial activity, Propolis extract, Pneumonia, Pseudomonas aeruginosa

*Correspondence: drsylvy80@gmail.com

(Received: August 12, 2019; accepted: November 30, 2019)

Citation: Sylvana N. Gaber, Eman Elsayed Mahmoud Hemeda, Hebat -Allah Sayed Elsayeh, Wafaa Y. Abdel Wahed, Mahmoud A.F. Khalil and Enas G.Ibrahim, Propolis Extract: A Possible Antiseptic Oral Care against Multidrug-Resistant Non-Fermenting Bacteria Isolated from Non-Ventilator Hospital-Acquired Pneumonia, J. Pure Appl. Microbiol., 2020; 14(1):123-131. https://doi. org/10.22207/JPAM.14.1.13

(C) The Author(s) 2020. Open Access. This article is distributed under the terms of the Creative Commons Attribution 4.0 International License which permits unrestricted use, sharing, distribution, and reproduction in any medium, provided you give appropriate credit to the original author(s) and the source, provide a link to the Creative Commons license, and indicate if changes were made. 


\section{INTRODUCTION}

Non-ventilator Hospital-acquired Pneumonia (NV-HAP) is one of the most common hospital-acquired infections (HAls). Even though it conveys similar mortality rates as VentilatorAssociated Pneumonia (VAP), its incidence rates are higher; thus, the accompanying charges and deaths could be more considerable ${ }^{1}$.

Three fundamental factors increase a patient's susceptibility to HAP: alterations in oral microorganisms (virulent gram-negative organisms), microaspiration (tiny droplets being aspirated), and a debilitated host. These factors generate a perfect environment for microorganisms to invade the respiratory area. In addition, neglected nursing care increased the likelihood of contracting NV-HAP triggered by an enlarged load of microbes ${ }^{2}$. Fortunately, one's risk in contracting pneumonia can be reduced by simple care procedures; for example, evaluating the patient's aspiration hazard, regular mobilization, and uplifting the head off the bed. Additionally, the decontamination of the respiratory tract by topical antiseptic agents is an applicant protective interference ${ }^{3}$.

Non-fermenting Gram-negative (GN) species, particularly $P$. aeruginosa and $A$. baumannii have long been documented as common and recurrent pathogens that cause HAP. It has been observed that $P$. aeruginosa is the second leading cause of HAP, right behind Staphylococcus aureus, which may account for $15 \%-20 \%$ of patients infected with $\mathrm{HAP}^{4}$. Additionally, A. baumannii has developed a substantial presence for HAP in intensive care units ${ }^{5}$. A. baumannii has been associated with a high mortality rate, which is approximately $35 \%$ to $70 \%$ of cases. ${ }^{6}$

Currently, clinicians are faced with bacterial strains, such as $P$. aeruginosa and Acinetobacter species that are resistant to the majority of antibiotics, resulting in HAls, with only a few available options ${ }^{7}$. Therefore, the development of new, naturally complementary, and alternative medicinal products against MDR GN pathogens is of the utmost importance in the field of HAls ${ }^{8}$.

Bees are insects belonging to the genus Apis. Bees are nature's developers and accumulators of honey, which is their primary product. However, bees also produce beeswax, royal jelly, bee venom, and propolis, which are derived from the excretion glands of the honeybee. It is worth mentioning that these products have been used for medicinal purposes for millennia?. Honey comprises approximately 200 celluar molecules, such as, vitamins, amino acids, enzymes, and minerals. However, honey is primarily composed of water and sugar (i.e., glucose and fructose). The antibacterial agents in honey provide inhibitory properties to Gram positive (GP) and GN bacteria. Honey has low mean $\mathrm{pH}$ of 4.4 , which is lethal to microorganisms. Even when honey is heavily diluted, the hydrogen peroxide activity of honey can still affect microbes by inhibiting their growth ${ }^{10}$.

Propolis is a resin-like material made by bees, produced through mixing beeswax and secretions of salivary glands with exudate collected from plants. Propolis is sometimes referred to as "bee penicillin"11. A beehive is a very sterile environment found in nature. Propolis not only acts as glue but is also used to clean and disinfect the honeycombs. Ancient Egyptians used it for preserving bodies during mummification. Recently, Egyptian propolis has become a topic of interest and is receiving increasing attention from chemists and biologists ${ }^{12}$.

Propolis is indicated in treating tuberculosis and upper respiratory tract infections, Human immunodeficiency Virus, H1N1 "swine" flu, and the common cold. Propolis contains phenolic substances, including flavonoids, with antimicrobial potential ${ }^{13}$.

Bee venom (BV) called apitoxin includes a combination of active enzymes, peptides, and amines. It is a colorless liquid with a pH of 5.0$5.5^{14}$. The antibacterial effect of BV has been recognized to be effective against Salmonella spp, Escherichia coli, Citrobacter freundii, Enterobacter cloacae, Coagulase-Negative Staphylococcus, and S. aureus ${ }^{10}$.

This study sought to assess the antibacterial effects of Egyptian Bee products (BPs): honey, propolis, and BV against MDR nonfermenting bacterial isolates collected from NVHAP patients as a possible antiseptic oral care. 


\section{MATERIAL AND METHODS Preparation of Bee products (BPs)}

The study was carried out in El- Zawia village at EL-FAYOUM Governorate, a city near middle Egypt. Ten colonies were used for honey, propolis, and bee venom collection. Honeycombs were taken from these colonies where they were weighed, followed by honey-extraction. A stock honey solution of $50 \%(\mathrm{w} / \mathrm{v})$ was prepared by liquefying $25 \mathrm{~g}$ of honey in $50 \mathrm{~mL}$ Muller-Hinton broth (Thermo Fisher Scientific Remel product, Lenexa, KS, USA) in a $50 \mathrm{~mL}$ flask. The solution was diluted for further analysis. Concentrations of honey were expressed as weight/volume percent (w/v \%). Propolis was gathered by collecting the hive scrapings while washing the honey supers throughout the honey harvest. The scrapings were covered with 5.08 to $7.62 \mathrm{~cm}$ of water and placed in an oven at $93.3^{\circ} \mathrm{C}$. The contents of the container were heated for approximately $2 \mathrm{~h}$ and were then moved. The liquefied wax is attached to pieces of wood, where it hangs to the surface of the water while the propolis attaches to the container bottom. After the container is detached from the oven and well-ventilated, the waxy layer on the surface of the water is detached, and the water is then cautiously poured off to reveal the colored propolis bulk underneath it. The cleaned propolis pieces are spread out on a piece of paper to dry before being stored. In total, $100 \mathrm{mg}$ of the propolis powder sample was homogenized with 10 $\mathrm{ml}$ of $70 \%$ alcohol for $30 \mathrm{~min}$. The alcoholic extract was separated by centrifugation at 6000-7000 rpm followed by evaporation. The electric shock method with the bee venom collector device was employed to gather the bee venom. The device was put vertically between the hive combs. Next, the collector device was used for $15 \mathrm{~min} /$ colony/ week. The deposited venom between the two glass sheets was dried, then scraped off by a razor blade. Finally, the bee venom was collected and placed into dark bottles in a powder form ${ }^{14}$.

Next, the physicochemical properties for honey, bee venom, and propolis were determined. Collecting bacterial isolates

From November 2017 to May 2018, twenty-three bacterial isolates were collected from the sputum, pleural fluid, and bronchial alveolar lavage of non-ventilator HAP patients who were admitted to the Fayoum University
Hospitals in Fayoum, Egypt. The following criteria emphasized the definition and characteristics of pneumonia: (1) The presence of at least one of the following: hyperpyrexia, increased or decreased leukocyte levels, altered mental status for adults $\geq 70$ years old. (2) Recent onset of purulent sputum, worsening cough, tachypnea or dyspnea, worsening gas exchange, or bronchial breath sounds. (3) Chest radiographs with one of the following: persistent infiltrate, recent or progressive consolidation, or cavitation. HAP was defined as pneumonia occurring within 48 $\mathrm{h}$ or more after hospitalization in non-ventilated cases $^{15}$. The samples were transported within $2 \mathrm{~h}$ to the Fayoum University Hospitals laboratories and were cultured on Macconkey agar plates (Oxoid Ltd., Basingstoke, England). Isolated bacteria were identified according to the standard microbiological methods ${ }^{16}$. For bronchial alveolar lavage: potential pathogens present at $\geq 1 \times 10^{4}$ colony-forming unit/ml (CFU/ml) were considered significant. Any $\mathrm{GN}$ rods were additionally recognized by the Microbact ${ }^{\mathrm{TM}}$ GNB 12A kit (Oxoid Ltd., Basingstoke, England) and aerobically incubated at $37^{\circ} \mathrm{C}$ for $24 \mathrm{~h}$. Testing of antibiotic susceptibility of the isolated colonies was performed according to the Clinical Laboratory Standards Institute (CLSI) guidelines ${ }^{17}$, by the disc diffusion method. The following antibiotics were tested: ampicillin(10 $\mu \mathrm{g})$, gentamicin(30 $\mu \mathrm{g})$, amoxicillin/clavulanic acid $(30 \mu \mathrm{g})$, aztreonam(30 $(3 \mathrm{~g})$, piperacillin/ tazobactam $(100 / 10 \mu \mathrm{g})$, tetracycline $(30 \mu \mathrm{g})$, meropenem $(10 \mu \mathrm{g})$, imipenem $(10 \mu \mathrm{g})$, cefoperazone $(30 \mu \mathrm{g})$, ceftazidime $(30 \mu \mathrm{g})$, cefotaxime $(30 \mu \mathrm{g})$, cefepime $(30 \mu \mathrm{g})$, cefoxitin $(30 \mu \mathrm{g})$, ciprofloxacin $(5 \mu \mathrm{g})$, chloramphenicol $(30 \mu \mathrm{g})$, trimethoprim/sulfamethoxazole $(25 \mu \mathrm{g})$, tigecycline $(15 \mu \mathrm{g})$, polymixin $(300 \mathrm{U})$, and fosfomycin $(50 \mu \mathrm{g})$. Additionally, MIC for colistin was performed. MDR-P. aeruginosa is defined as a strain resistant to one agent, in three or more antipseudomonal antimicrobial classes. $P$. aeruginosa ATCC 27853 was used as the control strain ${ }^{18}$.

\section{Antimicrobial activity of bee products by disc} diffusion test

The isolates were transported in a brain-heart infusion broth media to the research laboratory of Medical Microbiology and Immunology Department at the Fayoum University (Faculty of Medicine). For the detection 
of antibacterial activities of the BPs, the agar disc diffusion method was performed. The suspension of the tested bacteria $\left(10^{6} \mathrm{CFU} / \mu \mathrm{l}\right)$ was spread on Mueller Hinton agar (Oxoid Ltd., Basingstoke, England). Then, bacterial strains were incubated for $20 \mathrm{~min}$ at $37^{\circ} \mathrm{C}$. The agar was cut into discs of $5 \mathrm{~mm}$ in diameter, and wells were filled with $100 \mu \mathrm{L}$ containing $10 \%, 20 \%, 50 \%$, and $90 \%$ concentrations of BPs. They were incubated at $37^{\circ} \mathrm{C}$ for $24 \mathrm{~h}$. The inhibition zone diameters were detected in millimeters. The negative control was performed using distilled water. From triplicate measurements, the results were displayed as mean values ${ }^{34}$.

\section{Minimum inhibitory concentration determination (MIC) for Honey and Propolis}

The Minimum Inhibitory Concentrations (MICs) of honey and propolis were assessed by a microdilution technique as both honey and propolis showing the highest antimicrobial activity through the agar disc diffusion method. The tests were performed in 96-well plates (Corning ${ }^{\circledR}$ Costar $^{\circledR}$ Ltd., Corning, NY, USA) according to the CLSI guidelines ${ }^{19}$. Given that no diameter inhibitions were found at concentrations of $10 \%$, $20 \%$, and $50 \%$ of BPs, a volume of $100 \mu$ l of $90 \%$ BPs concentration ( $w / v)$ was distributed in wells. Positive and negative controls (broth) were tested. Subsequently, wells were seeded with an aliquot of $10 \mu \mathrm{l}$ of approximately $10^{6} \mathrm{CFU} / \mathrm{mL}$ of overnight bacterial culture and incubated for $24 \mathrm{~h}$ aerobically at $37^{\circ} \mathrm{C}$. The concentrations of BPs obtained in the well were between $45 \%$ and $0.01 \%$.

To determine the minimum bactericidal concentration determination (MBC) of honey and propolis, $10 \mu \mathrm{l}$ of content from the MIC wells were spread out without visible turbidity onto Mueller Hinton agar and incubating (aerobically) as required for evaluation. Positive and negative control wells were included. MBCs were determined on three separate occasions ${ }^{35}$.

\section{Ethical considerations}

This study was approved by the Faculty of Medicine Research Ethical Committee and Fayoum University Hospitals director. The study was conducted after explaining the study's aims. Statistical analysis

Using Statistical Package for Social Science (SPSS version 16, Chicago IL, USA), data were collected, coded, and analyzed. Data were quantified by calculating the means, median, standard deviation (SD), and interquartile range (IQR) for numerical data. Frequencies and percent were completed for qualitative data. A comparison of quantitative variables was made using the Mann-Whitney $U$ test between two groups and Kruskal-Wallis $\mathrm{H}$ tests (i.e., one-way ANOVA on ranks) for more than two groups. $P \leq 0.05$ was considered statistically significant.

\section{RESULTS}

A total of twenty-three isolates were collected from NV-HAP patients. Eighteen isolates were $P$. aeruginosa, and five isolates were $A$. baumannii.

$P$. aeruginosa isolates revealed a high resistance rate to meropenem and imipenem (55.6\% and $77.8 \%$, respectively). Additionally, all $P$. aeruginosa isolates were susceptible to polymyxin and colistin (Table 1). A. baumannii isolates were found to be resistant to all tested antibiotics except for colistin and polymyxin.

Table 1. Antibiogram of the isolated $P$. aeruginosa

\begin{tabular}{cc}
\hline Antibiotics & Resistance (\%) \\
\hline AMP & 100 \\
AMC & 100 \\
CTX & 100 \\
CRO & 100 \\
CAZ & 100 \\
EFP & 72.2 \\
TZP & 94.4 \\
ATM & 77.8 \\
IPM & 77.8 \\
MPE & 55.6 \\
CIP & 77.8 \\
GN & 72.2 \\
TE & 100 \\
TGC & 94.4 \\
SXT & 100 \\
C & 100 \\
FOX & 88.9 \\
PB & 0 \\
FOS & 11.1 \\
\hline
\end{tabular}

AMP: ampicillin, AMC: amoxicillin / clavulanic acid, CTX: cefotaxime, CRO: cefaprazone, CAZ: ceftazidime FEP cefepime, TZP: piperacillin-tazobactam, ATM: aztreonam, IPM: imipenem, MEP: meropenem, CIP: ciprofloxacin, GN: gentamicin, TE: tetracycline, FOX: cefoxitin, C: Chloramphenicol, TGC: tigecycline, SXT: sulfamethoxazole/ trimethoprim, FOS: fosfomycin PB: polyimixin 


\section{Physicochemical properties of bee products}

The physicochemical properties of propolis are comprised of the following flavonoids: quercetin, kaempferol, acacetin, isovanillin, pinostrobin, ramnocitrin, 5- hydroxy-7,4dimethoxy flavone, 5,7-hydroxy -3,4- dimethoxy flavone, 3,5- dihydroxy-4,7-dimethoxy flavone, and 5-hydroxy- 7,4-dimethoxy flavone. The physicochemical properties of honey are comprised of the following: $31 \% \mathrm{~g}$ lucose, $38.2 \%$ fructose, $7.2 \%$ maltose, $4.2 \%$ higher carbohydrates, $1.5 \%$ sucrose, $17.1 \%$ water, minerals, vitamins, and enzymes. The physicochemical properties of bee venom are summarized in Table 2.

Table 2. Composition of Bee Venom and its percentage

\begin{tabular}{|c|c|c|}
\hline Class & Compound & percentage $\%$ \\
\hline \multirow[t]{4}{*}{ 1. Enzymes } & $\begin{array}{l}\text { Phospholipase A2 } \\
\text { phospholipase B }\end{array}$ & $10-12 \% 1 \%$ \\
\hline & Hyaluronidase & $1-2 \%$ \\
\hline & Phosphatase & $1.0 \%$ \\
\hline & a - Glucosidase & $0.6 \%$ \\
\hline \multirow{9}{*}{$\begin{array}{l}\text { 2. Proteins and } \\
\text { peptides }\end{array}$} & Melittin & $40-50 \%$ \\
\hline & Apamine & $2-3 \%$ \\
\hline & Mast Cell & $2-3 \%$ \\
\hline & $\begin{array}{l}\text { Degranulating } \\
\text { peptide }\end{array}$ & $0.5-2 \%$ \\
\hline & Secapine & $1-32 \%$ \\
\hline & Pamine & $0.5-1 \%$ \\
\hline & Minimine & $1-2$ \\
\hline & Adolapine & $\% 0.1-0.8 \%$ \\
\hline & & $1-2 \%$ \\
\hline \multirow[t]{3}{*}{ 3. Amines } & Histamine & $0.5-2 \%$ \\
\hline & Dopamine & $0.13-1 \%$ \\
\hline & Norepinephrine & $0.1-0.7 \%$ \\
\hline 4. Carbohydrates & $\begin{array}{l}\text { Glucose and } \\
\text { fructose }\end{array}$ & $2 \%$ \\
\hline 5. Amino acids & $\begin{array}{l}\text { Amino butyric } \\
\text { acid \&Alpha- } \\
\text { amino acids }\end{array}$ & $1 \%$ \\
\hline $\begin{array}{l}\text { 6. Volatile } \\
\text { ingredients }\end{array}$ & Complex Ether & $4-8 \%$ \\
\hline 7. Minerals & $\mathrm{P}, \mathrm{Ca}, \mathrm{Mg}$ & $3-4 \%$ \\
\hline
\end{tabular}

Antimicrobial activity of Bee Products

At the concentration of $90 \%(w / v)$, the inhibitory effect of BPs on bacterial growth was apparent. Significant differences in inhibition zone values, MIC, and MBC values for propolis in comparison to honey and bee venom $(p<0.001)$ were found (Table 3,4$)$. The best antibacterial
Table 3. Result of the Disc Diffusion method in millimeter $(\mathrm{mm})$ of Bee Products against the studied isolates

\begin{tabular}{lcccc}
\hline & $\begin{array}{c}\text { Bee } \\
\text { Venom }\end{array}$ & Propolis & Honey & $\begin{array}{c}\text { P- } \\
\text { value }\end{array}$ \\
\hline Mean & $\begin{array}{c}4.7 \mathrm{~mm} \\
\text { SD }\end{array}$ & $\begin{array}{c}21.9 \mathrm{~mm} \\
6.643\end{array}$ & $\begin{array}{c}14.678 \\
6.700\end{array}$ & $<0.001$ \\
\hline
\end{tabular}

Kruskal- Wallis test was done

$P$ value $\leq 0.05$ indicated a statistically significant

Table 4. Result of the Minimum inhibitory concentration $\%(\mathrm{MIC})$ and Minimum bactericidal concentration $\%(\mathrm{MBC})$ of Honey and Propolis against the studied isolates

\begin{tabular}{lccc}
\hline & $\begin{array}{c}\text { MIC of } \\
\text { Propolis \% }\end{array}$ & $\begin{array}{c}\text { MIC of } \\
\text { honey \% }\end{array}$ & P-value \\
\hline Mean & 7.1 & 20.6 & $<0.001$ \\
SD & 5.9 & 23.8 & \\
Median & $5.6(2.8-11.3 \%)$ & $11.3(5.6-22.5 \%)$ & \\
(IQR) & MBC of & MBC of & $<0.001$ \\
& Propolis \% & honey \% & \\
Mean & 17.01 & 28.4 & \\
SD & 9.38 & 11.67 & \\
Median & & & \\
( IQR) & $22.5(11.3-22.5)$ & $22.5(22.5->45.0)$ & \\
\hline
\end{tabular}

Mann-Whitney Utes was done

activity was observed for propolis against P.aeruginosa $(13-36 \mathrm{~mm}$, MIC $=1.4-22.5 \%$ with a mean $6.3 \%$ and $\mathrm{MBC}=2.8-45 \%$ with a mean $17 \%)$ and against $A$. baumannii $(7-20 \mathrm{~mm}$, $\mathrm{MIC}=5.6-22.5 \%$ with a mean $10 \%$, and $\mathrm{MBC}=11.3$ $-22.5 \%$ with a mean $18 \%$ ). This was followed by honey, that led to generation of a diameter zone of inhibition for $P$. aeruginosa $(9-28 \mathrm{~mm}$ with $\mathrm{MIC}=5.6-45 \%$ with a mean $15 \%$, and $\mathrm{MBC}=11.3-$ $>45 \%$ with a mean $26 \%$ ); for $A$. baumanni the resultant diameter zone of inhibition was (0-16 $\mathrm{mm}, \mathrm{MIC}=11.3-45 \%$ with a mean $18 \%$, and $\mathrm{MBC}=$ $22.5->45 \%$ with a mean $36 \%$ ). Bee venom showed the least amount of activity against all isolates with a diameter zone of inhibition $(0-12 \mathrm{~mm}$ with mean: $4.7 \mathrm{~mm})$. MBC 50 and MBC 90 for honey and propolis are shown in Table 5. 
Table 5. Result of the MIC50 MIC 90, MBC 50, and $\mathrm{MBC} 90$ of Propolis and honey for the studied isolates

\begin{tabular}{lcccc}
\hline Bee & MIC & MIC & MBC & MBC \\
\hline Products & 50 & 90 & 50 & 90 \\
Propolis & 5.6 & 22.5 & 22.5 & 22.5 \\
Honey & 11.3 & 45 & 22.5 & $>45$ \\
\hline
\end{tabular}

Minimum inhibitory concentration ( MIC)

Minimum bactericidal concentration ( MBC)

\section{DISCUSSION}

Several hypotheses have explained the possible role of oral bacteria in the pathogenesis of respiratory diseases like pneumonia ${ }^{20}$. $P$. aeruginosa and $A$. baumannii are important etiological factors of HAP, having a prominent ability to resist multiple categories of antibiotics ${ }^{21}$ Thus, research and investigation into potential antibacterials are currently of great interest. In recent times, public awareness in the therapeutic use of bee products has dramatically increased, especially since they have no reported record of adverse side effects on tissues ${ }^{22}$.

In the current work, among 18 isolates of $P$. aeruginosa, high resistance rates to meropenem and imipenem (55.6\% and $77.8 \%$ respectively) were found. Additionally, five A. baumannii isolates were found to be resistant to all the antibiotics used in this study. These results were in agreement with the results reported by Liu et al. who reported the rates of resistance of $P$. aeruginosa to meropenem and imipenem (48.8\% and $70.7 \%$, respectively), and high resistance rates of $A$. baumannii to carbapenems (more than $70 \%$ ) were found ${ }^{23}$. Moreover, Chung et al. found $P$. aeruginosa with a resistance rate to imipenem (56.9\%), and Acinetobacter spp. presented a high rate of resistance to imipenem $(67.3 \%)^{24}$. All isolates in our study persisted in being sensitive to colistin. However, in this report: the resistance rate to colistin was observed to be $0.8 \%$.

Several scientific studies showed propolis having antibacterial activity (with active constituents including flavonoids like galanin and hydroxyl-cinnamic acids) ${ }^{25}$. The synergistic activity between various active constituents has been attributed as the chief reason for getting the complex antibacterial effect of propolis ${ }^{26}$.
Campos et al in Brazil aimed to study the biological properties and chemical composition of propolis. They reported legitimate antimicrobial activity of propolis, MIC for $P$. aeruginosa was $5.83 \mathrm{mg} / \mathrm{mL}$, and $\mathrm{MBC}$ was $14.42 \mathrm{mg} / \mathrm{ml}^{27}$. While Seidel et al. documented that propolis samples of European, North American, and South American origin had a MIC extending from 0.125 to $>0.5 \mathrm{mg} /$ $\mathrm{mL}$ whereas, African and Asian origin had a MIC extending from 0.08 to $>0.5 \mathrm{mg} / \mathrm{ml}^{28}$. Furthermore, Aissat et al. in Algeria reported propolis activity for $P$. aeruginosa was 9-19 $\mathrm{mm}$, MIC in range of $17 \%-57 \%^{29}$. These antimicrobial activity results have differed from our findings in which Egyptian propolis showed antibacterial activity against $P$. aeruginosa at $13-36 \mathrm{~mm}, \mathrm{MIC}=1.4-22.5 \%$ with a mean value of $6.3 \%$, and $\mathrm{MBC}=2.8-45 \%$ with a mean value of $17 \%$. Additionally, our study reported activity of propolis against $A$. baumannii to be the following: $7-20 \mathrm{~mm}, \mathrm{MIC}=5.6-22.5 \%$ with a mean value of $10 \%$, and $\mathrm{MBC}=11.3-22.5 \%$ with a mean value of $18 \%$. Hannan et al. in Pakistan aimed to determine the antibacterial activity of propolis for $A$. baumannii from two sites and observed that propolis from Sargodha and Lahore displayed inhibition zone diameters of $21.8 \mathrm{~mm}$ and $15.6 \mathrm{~mm}$, respectively. MIC values of propolis from Sargodha and Lahore were from 1.5-2.0 mg/ $\mathrm{ml}$ and $4.0-4.5 \mathrm{mg} / \mathrm{ml}$, respectively ${ }^{30}$.

Many researchers have shown that Acinetobacter spp exhibited either low sensitivity or total absence of sensitivity against propolis. ${ }^{12,31,32}$ These variations in the antibacterial activity of propolis among different studies could be due to the differences in origin.

In the present study, the antimicrobial activity of honey against MDR non-fermenter bacteria were less than propolis, which the diameter zone of inhibition of honey for $P$. aeruginosa was 9-28 $\mathrm{mm}$ with $\mathrm{MIC}=5.6-45 \%$ and $\mathrm{MBC}=11.3->45 \%$, and for $A$. baumannii was $0-16 \mathrm{~mm}$ with $\mathrm{MIC}=11.3-45 \%$, and $\mathrm{MBC}=$ $22.5->45 \%$. Those results were higher than the results reported by Henriques et al. who found the values of MIC and MBC of manuka honey against $P$. aeruginosa $(9.5 \%$ and $12 \%$, respectively $)^{33}$. However, they were lower than the results revealed by Moussa et al. who observed the diameter zone of inhibition of honey for $P$. 
aeruginosa to be $0-30 \mathrm{~mm}$ while the MIC ranged around $90-91 \%{ }^{34}$. Additionally, Al-Nahari et al. found that all tested types of honey employed a complete inhibition of bacterial growth at $50 \%{ }^{35}$. Furthermore, Wilkinson \& Cavanagh concluded that 13 types of studied honey had an inhibitory effect on $P$. aeruginosa ${ }^{36}$. Tirado et al. reported that the MIC and MBC of the Medihoney was $8.5 \%$, and $0.5 \%$, respectively, for $A$. baumannii ${ }^{37}$. Adam also found $A$. baumannii susceptible to honey at a minimum concentration of $50 \%$ and $100 \%{ }^{38}$. Contrarily, Basson \& Grobler found no antimicrobial activity for honey native to South Africa ${ }^{39}$. Kuś et al. tested 30 Polish monofloral honey-types and observed the type that had the highest antimicrobial activity was still dramatically less active against $P$. aeruginos $a$ with values of MIC extended from 6.25 to $25 \%{ }^{40}$. It has been revealed that honey might have antibacterial action from less than $3 \%$ to $50 \%$ or higher concentrations ${ }^{36}$. These results from different studies approved that honey from diverse regions and countries could have vast differences in their antibacterial activity.

Our results demonstrated little activity of bee venom against all isolates with zone diameter from 0-12 $\mathrm{mm}$ with mean: 4.7. Zolfagharian et al. agreed with our results, who evaluated the antimicrobial effect of bee venom against six GP and GN bacteria and found bee venom had no noticeable effect on $P$. aeruginos $a^{14}$. Also, Fennell et al. reported that the bee venom is more active against GP than GN bacteria ${ }^{41}$.

The findings of our study showed that propolis had good antimicrobial activity against MDR non- fermenting bacteria, which helps to be used as a possible oral antiseptic in pneumonic patients.

\section{CONCLUSION}

Given the promising antimicrobial activity of propolis, low cost, and safety, we suggest its potential application as an oral antiseptic to reduce the NV-HAP incidence. Further investigation is warranted to confirm these promising findings, and additional studies on varied kinds of GP and GN bacteria are needed, and in vivo activity of propolis for the pneumonic patients would be essential for the assessment of its efficacy in pneumonia prevention.

\section{ACKNOWLEDGMENTS}

All authors acknowledge help from all paramedical personals to accomplish and finalize our research.

\section{CONFLICT OF INTEREST}

conflict of interest.

The authors declare that there is no

\section{FUNDING}

The research was funded personally and by Microbiology and Immunology Department, Faculty of Medicine, Fayoum University.

\section{DATA AVAILABILITY}

All datasets generated or analyzed during this study are included in the manuscript.

\section{AUTHORS' CONTRIBUTION}

S.N.G, Invited the idea, Share in writing, editing of the manuscript, Share in actual laboratory work. E.G.I, Share in writing, final editing of the manuscript, searched database. E.E.M, Collection of the bacterial samples, searched database. H.S.Elsayeh, Collection of Bee product samples, searched database. W.Y.A.W, Statistical analysis, Share in final English language editing. M.A.F.K, Share in actual laboratory work, Share in final English language editing.

\section{ETHICS STATEMENT}

This article does not contain any studies with human participants or animals performed by any of the authors.

\section{REFERENCES}

1. Quinn B, Baker DL, Cohen S, Stewart JL, Lima CA, Parise C. Basic nursing care to prevent non-ventilator hospital-acquired pneumonia. J. Nurs. Scholarsh, 2014; 46(1): 11-9. https://doi.org/10.1111/jnu.12050

2. Kieninger, A \& Lipsett, P. Hospital-acquired pneumonia: Pathophysiology, diagnosis, and treatment. Surgical Clinics of North America, 2009; 89(2): 439-61. https:// doi.org/10.1016/j.suc.2008.11.001

3. Pileggi C, Bianco A, Flotta D, Nobile CG, Pavia M. Prevention of ventilator-associated pneumonia, mortality and all intensive care unit acquired infections by topically applied antimicrobial or antiseptic agents: a meta-analysis of randomized controlled trials in intensive care units. Crit. Care, 2011; 15(3). https:// doi.org/10.1186/cc10285

4. Rello J, Sa-Borges M, Correa H, Leal SR, Baraibar 
J. Variations in etiology of ventilator-associated pneumonia across four treatment sites: implications for antimicrobial prescribing practices. Am. J. Respir. Crit. Care Med., 1999; 160: 608-13. https://doi. org/10.1164/ajrccm.160.2.9812034

5. Joung MK, Kwon $\mathrm{KT}$, Kang $\mathrm{Cl}$, Cheong HS, Rhee JY, Jung DS, et al. Impact of inappropriate antimicrobial therapy on outcome in patients with hospital-acquired pneumonia caused by Acinetobacter baumannii. Journal of Infection. 2010; 61: 212-18. https://doi. org/10.1016/j.jinf.2010.06.014

6. Gaynes R \& Edwards JR. Overview of nosocomial infections caused by gram-negative bacilli. Clin. Infect. Dis., 2005; 41: 848e54. https://doi. org/10.1086/432803

7. Paterson DL. The Epidemiological Profile of Infections with Multidrug-Resistant Pseudomonas aeruginosa and Acinetobacter Species. CID, 2006; 43: S43-8. https://doi.org/10.1086/504476

8. Poulakou G, Lagou S, Karageorgopoulos DE, Dimopoulos G. New treatments of multidrug-resistant Gram-negative ventilator-associated pneumonia. Ann. Trans/ Med., 2018; Nov; 6(21): 423. https://doi. org/10.21037/atm.2018.10.29

9. Cornara L, Biagi M, Xiao J, Burlando B. Therapeutic Properties of Bioactive Compounds from Different Honeybee Products. Front. Pharmacol., 2017; 8: 412. https://doi.org/10.3389/fphar.2017.00412

10. Bouacha $\mathrm{M}$, Ayed $\mathrm{H}$, and Grara N. Honey Bee as Alternative Medicine to Treat Eleven MultidrugResistant Bacteria Causing Urinary Tract Infection during Pregnancy. Sci. Pharm., 2018; 86(2). https:// doi.org/10.3390/scipharm86020014

11. Oryan A, Alemzadeh E, and Moshiri A. Potential role of propolis in wound healing: Biological properties and therapeutic activities. Biomed. Pharmacother., 2018; 98: 469-83. https://doi.org/10.1016/j. biopha.2017.12.069

12. Abd E Hady FK \& Hegazi AG. Egyptian propolis: 2. Chemical composition, antiviral and antimicrobial activities of East Nile Delta propolis. Z. Naturforsch C. 2002; 57(3-4): 386-94. https://doi.org/10.1515/ znc-2002-3-431

13. Veiga FF, Gadelha MC, da Silva MRT, Costa MI, Kischkel B, de Castro-Hoshino LV, Sato F, Baesso ML, et al. Propolis Extract for Onychomycosis Topical Treatment: From Bench to Clinic. Front. Microbiol., 2018; 9: 779. https://doi.org/10.3389/fmicb.2018.00779

14. Zolfagharian H, Mohajeri M and Babaie M. Bee Venom (Apis Mellifera) an Effective Potential Alternative to Gentamicin for Specific Bacteria Strains: Bee Venom an Effective Potential for Bacteria. J. Pharmacopuncture., 2016; 19(3): 225-30. https://doi.org/10.3831/ KPI.2016.19.023

15. Horan TC, Andrus M, and Dudeck MA. CDC/NHSN surveillance definition of health care-associated infection and criteria for specific types of infections in the acute care setting. Am. J. Infect. Control, 2008; 36: 309-32. https://doi.org/10.1016/j.ajic.2008.03.002

16. Mahon C\& Manuselis JR. Diagnostic microbiology. W.B. Saunders Company, Philadelphia, 2000; 1165.
17. Clinical and Laboratory Standards Institute (CLSI). Performance standards for antimicrobial susceptibility testing. CLSI supplement M100S. 26th ed. Wayne, PA: Clinical and Laboratory Standards Institute; 2016.

18. Palavutitotai $N$, Jitmuang A, Tongsai $S$, Kiratisin $P$, Angkasekwinai N. Epidemiology and risk factors of extensively drug-resistant Pseudomonas aeruginosa infections. PLoS One, 2018; 13(2): e0193431. https:// doi.org/10.1371/journal.pone.0193431

19. Wiegand I, Hilpert K and Hancock RE. Agar and broth dilution methods to determine the minimal inhibitory concentration (MIC) of antimicrobial substances. Nat. Protoc., 2008; 3: 163-75. https://doi.org/10.1038/ nprot. 2007.521

20. Gomes-Filho IS, Passos JS, and Seixas da Cruz S. Respiratory disease and the role of oral bacteria. J. Oral Microbiol., 2010; 2. https://doi.org/10.3402/jom. v2i0.5811

21. Cho HH, Kwon GC, Kim S, and Koo SH. Distribution of Pseudomonas-Derived Cephalosporinase and Metallo- $\beta$-Lactamases in Carbapenem-Resistant Pseudomonas aeruginosa Isolates from Korea. J. Microbiol Biotechnol., 2015; 25(7): 1154-62. https:// doi.org/10.4014/jmb.1503.03065

22. Yuksel S \& Akyol S. The consumption of propolis and royal jelly in preventing upper respiratory tract infections and as dietary supplementation in children. J. Intercult Ethnopharmacol., 2016; 5(3): 308-11. https://doi.org/10.5455/jice.20160331064836

23. Liu YN, Cao B, Wang H, Chen LA, She DY, Zhao TM, Liang ZX, Sun TY et al. Adult hospital acquired pneumonia: a multicenter study on microbiology and clinical characteristics of patients from 9 Chinese cities. Zhonghua Jie He He Hu Xi Za Zhi, 2012; 35(10):739-46.

24. Chung DR, Song JH, Kim SH, Thamlikitkul V, Huang SG, Wang H, So TM, Yasin RM et al. High prevalence of multidrug-resistant non-fermenters in hospitalacquired pneumonia in Asia. Am. J. Respir. Crit. Care Med., 2011; 184(12): 1409-17. https://doi. org/10.1164/rccm.201102-03490C

25. Hasson SO. Antibacterial activities of iraqi propolis and its active components extracts on some bacterial isolates (in vitro study). World Journal of Pharmacy and Pharmaceutical Sciences, 2014 ; 3(2):858.

26. Al-Ani I, Zimmermann S, Reichling J, Wink M. Antimicrobial Activities of European Propolis Collected from Various Geographic Origins Alone and in Combination with Antibiotics. Medicines (Basel). 2018; 5(1). https://doi.org/10.3390/medicines5010002

27. Campos JF, Dos Santos UP, da Rocha Pdos S, Damiao MJ, Balestieri JB, Cardoso CA et al. Antimicrobial, Antioxidant, Anti-Inflammatory, and Cytotoxic Activities of Propolis from the Stingless Bee Tetragonisca fiebrigi (Jatai). Evid Based Complement Alternat Med., 2015: 296186. https://doi.org/10.1155/2015/296186

28. Seidel V, Peyfoon E, Watson DG, Fearnley J. Comparative study of the antibacterial activity of propolis from different geographical and climatic zones. Phytother. Res., 2008; 22: 1256-63. https://doi.org/10.1002/ ptr. 2480

29. Aissat S, Ahmed M and Djebli N. Propolis-Sahara 
honeys preparation exhibits antibacterial and antibiofilm activity against bacterial biofilms formed on urinary catheters. Asian Pacific Journal of Tropical Disease, 2016; 6(11): 873-77. https://doi.org/10.1016/ S2222-1808(16)61149-0

30. Hannan A, Batool A, Qamar MU, Khalid F. Propolis as an antibacterial agent against clinical isolates of mdr-acinetobacter baumannii. J. Ayub Med. Coll. Abbottabad, 2015; 27(1): 216-9.

31. Gonzalez BG, Martinez-Aguilar G, and Hulten KG. Severe staphylococcal sepsis in adolescents in the era of community acquired methicillin-resistant Staphylococcus aureus. Pediatrics, 2005; 115: 642-648. https://doi.org/10.1542/peds.2004-2300

32. Moreno MIN, Isia MI, Sampietro AR, and Vattuone MA. Comparison of the free radical- scavenging activity of propolis from several regions of Argentina. J. Ethnopharmacol., 2000; 71: 109-14. https://doi. org/10.1016/S0378-8741(99)00189-0

33. Henriques AF, Jenkins RE, Burton NF, Cooper RA. The effect of manuka honey on the structure of Pseudomonas aeruginosa. Eur. J. Clin. Microbiol. Infect. Dis., 2011; 30(2): 167-71. https://doi.org/10.1007/ s10096-010-1065-1

34. Moussa A, Noureddine D. Abdelmelek M, Saad A. Antibacterial activity of various honey types of Algeria against Pathogenic Gram-Negative Bacilli: Escherichia coli and Pseudomonas aeruginosa. Asian Pacific Journal of Tropical Disease, 2012; 2(3): 211-14. https:// doi.org/10.1016/S2222-1808(12)60048-6

35. Al-Nahari AA, Almasaudi SB, Abd El-Ghany el SM, Barbour E, Al Jaouni SK, Harakeh S. Antimicrobial activities of Saudi honey against Pseudomonas aeruginosa. Saudi J. Biol. Sci., 2015; 22(5): 521-5. https://doi.org/10.1016/j.sjbs.2015.04.006

36. Wilkinson JM\& Cavanagh HM. Antibacterial activity of 13 honeys against Escherichia coli and Pseudomonas aeruginosa. J. Med. Food, 2005; 8: 100-3. https://doi. org/10.1089/jmf.2005.8.100

37. Tirado DJ, Hudson NR, and Maldonado CJ. Efficacy of medical grade honey against multidrug-resistant organisms of operational significance: part I. J. Trauma Acute Care Surg., 2014; 77(3 Suppl 2): S204-7. https:// doi.org/10.1097/TA.0000000000000324

38. Adam AE. Antimicrobial activity of Bee honey, black cumin oil and green tea against multidrug resistant pathogenic bacteria. Int.J. Curr. Microbiol. App.Sci., 2013; 2(12): 58-63.

39. Basson NJ \& Grobler SR. Antimicrobial activity of two South African honeys produced from indigenous Leucospermum cordifolium and Erica species on selected micro-organisms. BMC Complement Altern Med., 2008; 8: 41. https://doi.org/10.1186/14726882-8-41

40. Kus PM, Szweda P, Jerkovic I, Tuberoso Cl. Activity of Polish unifloral honeys against pathogenic bacteria and its correlation with colour, phenolic content, antioxidant capacity and other parameters. Lett. Appl. Microbiol., 2016; 62(3): 269-76. https://doi. org/10.1111/lam.12541

41. Fennell JF, Shipman WH, and Cole LJ. Antibacterial action of melittin, a polypeptide from bee venom. Proc. Soc. Exp. Biol. Med., 1968; 127(3): 707-10. https://doi. org/10.3181/00379727-127-32779 